\title{
Salicylic Acid Concentrations and Its Effects on the Physiological Quality of Soybean Seeds
}

\author{
Joner S. Dalcin ${ }^{1}$, Ubirajara R. Nunes ${ }^{2}$, Rodrigo Roso ${ }^{1}$, Caren A. Müller ${ }^{1}$, Fernanda A. A. L. Backes ${ }^{2}$, \\ Rogério L. Backes ${ }^{2}$, Nilson M. Mattioni ${ }^{2}$, Alberto Cargnelutti Filho ${ }^{2}$, Cassiano V. dos Santos ${ }^{1}$, \\ Mariana B. F. de Mendonça ${ }^{3}$, Géssica G. de Bastiani ${ }^{1}$, Geovana F. Barbieri ${ }^{3}$ \& Raquel Stefanello ${ }^{1}$ \\ ${ }^{1}$ Postgraduate Program in Agronomy, Federal University of Santa Maria, Santa Maria, Brazil \\ ${ }^{2}$ Department of Crop Science, Federal University of Santa Maria, Santa Maria, Brazil \\ ${ }^{3}$ Graduation in Agronomy, Federal University of Santa Maria, Santa Maria, Brazil \\ Correspondence: Joner S. Dalcin, Postgraduate Program in Agronomy, Federal University of Santa Maria, \\ Avenida Roraima, $n^{\circ}$ 1000, Bairro Camobi, CEP: 97105-900, Santa Maria, RS, Brazil. Tel: (55)-99-724-0414. \\ E-mail: joner_dalcin@yahoo.com.br
}

Received: August 3, 2019

doi:10.5539/jas.v11n17p271
Accepted: September 11, 2019

Online Published: October 15, 2019

URL: https://doi.org/10.5539/jas.v11n17p271

\begin{abstract}
The objective of this study was to evaluate the physiological quality of commercial soybean seeds submitted to different concentrations of salicylic acid (SA), directly on germination paper and gerboxes for 24 hours. Seeds of cultivars NA 5909 RG and Tec Irga 6070 RR were soaked in salicylic acid solutions with concentrations of zero, 250, 500, 750, 1000, 1500, 2000, 3000, 4000 and $5000 \mu \mathrm{M}$. Seed imbibition occurred in two ways: (1) germination paper moistened with salicylic acid solutions; (2) imbibition of the seeds in salicylic acid solutions in gerbox boxes for 24 hours and subsequent sowing on germinated paper moistened with distilled water. On the fifth day after sowing, the number of normal seedlings (first count), length, fresh and dry mass of root and shoot were determined. It was concluded that the concentrations of SA between 250 and $750 \mu \mathrm{M}$ can be used in soybean seeds, however, above $1000 \mu \mathrm{M}$ may impair the parameters of physiological quality. The gerbox method for 24 hours provided the best results without the drastic reduction of the parameters in the lowest concentrations of SA.
\end{abstract}

Keywords: vigor, germination, imbibition

\section{Introduction}

Soybean cultivation is of global importance in agribusiness because it is used for different objectives, both for animals and humans (Fioreze et al., 2011). The demand for higher productivity is achieved with the use of techniques and management, and the beginning of a crop will only have uniformity with the use of seeds with high physiological potential (Marcos Filho, 2015a). However, biotic and abiotic stresses may decrease yield throughout the growing season in the field, from germination to harvesting (Danquah et al., 2014; Jaleel et al., 2009; Morando et al., 2014).

To maintain its capacity to tolerate stresses, the plant uses its complex defense system, which is composed of different mechanisms and specific compounds that aid in this process (Yang \& Dong, 2014). Among these, salicylic acid (SA) is considered a plant hormone present in numerous plant species and acts in important biochemical and physiological processes, such as growth and development, stomatal closure, nutrient absorption, chlorophyll and protein synthesis, foliar abscission and seed germination (Hayat, 2010; Miura \& Tada, 2014; Vazirimehr \& Rigi, 2014). In addition, it has an influence on the response to different types of stress, through chemical signaling in plant cells together with antioxidant complex enzymes (Janda et al., 2014; Parmoon et al., 2017). Also, other enzymes such as superoxide dismutase, peroxidases, catalases, among others, have the function of reducing the damage caused by free radicals, such as reactive oxygen species (ROS), which are formed mainly in moments of stress (Hayat et al., 2012; Lee, Kim, \& Park, 2010).

Studies that perform the exogenous application of SA do not have consensus about the concentration to be used, the time of contact or route for absorption. There is concrete information that low concentrations of SA aid in antioxidant capacity; already, high concentrations may lead to oxidative stress or susceptibility to abiotic stress 
(Miura \& Tada, 2014). However, each situation may be influenced by the study conditions, which consequently increase the variability of the results. As an example, Kang et al. (2012) observed that high concentrations decreased important parameters in the wheat crop, such as lower seedling growth, increased activity of antioxidant enzymes, decreased photosynthesis, thus increasing plant stress levels.

Tang et al. (2017) point out that the concentration of $0.5 \mathrm{mM}$ and osmotic potential of $-1.03 \mathrm{MPa}$ in the germination of soybean seeds reduced the effect of high water stress. Similarly, Al-Hakimi (2006) suggested that the concentration of $0.6 \mathrm{mM}$ SA promoted a water deficit inhibitory effect on several parameters evaluated in leaves and roots. However, the role of SA and its various functions in the plant defense system is not yet known, so studies that specifically elucidate its performance are needed (Janda \& Ruelland, 2015).

It is noticed that although there are several studies using SA, a pattern of concentrations and mode of imbibition of the compound after seed germination has not yet been established. Therefore, the objective of the study was to verify the effect of different concentrations of SA on some parameters of physiological quality in soybean commercial seeds.

\section{Material and Methods}

The study was conducted at the Laboratory of Seed Research and Development (LDPS) of the Department of Plant Science at the Federal University of Santa Maria, in the Rio Grande do Sul state. Commercial soybean seeds of Nidera ${ }^{\circledR}$ NA 5909 RG and Bayer ${ }^{\circledR} /$ Tec Irga 6070 RR cultivars produced in the 2015/2016 crop were used, both of which are recommended for cultivation in the state.

Initial evaluation of seeds: samples from both cultivars were evaluated separately for physical and physiological characteristics by performing the following tests: thousand seed weight, moisture content, first count of germination, germination test, root and shoot length, dry mass of seedlings, mass electrical conductivity and emergence of seedlings on field (Krzyzanowski; Vieira, \& França Neto, 1999; Nakagawa, 1999; Brasil, 2009).

Physiological quality of soybean seeds submitted to SA concentrations: after the initial characterization, the seeds were submitted to germination under different concentrations of SA (Sigma-Aldrich ${ }^{\circledR}$ ): zero; 250; 500; $750 ; 1000 ; 1500 ; 2000 ; 3000 ; 4000 ; 5000 \mu \mathrm{M}$. In the literature, there are different studies including soybean, but there is no consensus among researchers of the most adequated concentration (Al-Hakimi, 2006; Tang et al., 2017).

The SA was supplied to the seeds in two forms: (1) in the germinated paper moistened with the SA solutions; (2) imbibition of the seeds in SA solutions in gerbox for 24 hours. For the first group, four replications of 50 seeds were sown on rolls of germination paper with the SA solutions mentioned, in the proportion of 2.5 times the weight of the dry paper. The rolls were packed in plastic bags and kept in a BOD (Box Organism Development) germination chamber under constant light and temperature of $25^{\circ} \mathrm{C}$.

In the second option, four replicates of 50 seeds were placed in gerbox boxes to soak on three sheets of germinating paper moistened with $25 \mathrm{~mL}$ of SA solution at the same concentrations. The seeds remained soaked for 24 hours in BOD under constant light and temperature of $25^{\circ} \mathrm{C}$. After this imbibition period, the seeds were placed to germinate on germinated paper moistened only with distilled water, in the proportion of 2.5 times the dry paper mass. The rolls were packed in plastic bags, kept in BOD, under continuous light and at $25^{\circ} \mathrm{C}$ (Brasil, 2009).

For both ways of SA treatment, on the fifth day after sowing, the percentage of normal seedlings was evaluated and, at the eighth day, the percentage of germination was estimated according to Brazil (2009). In addition to the germination test, on the fifth day after sowing, ten normal seedlings were removed in sequence from the upper part of the germinating roller, to compose the length, fresh and dry mass of root and shoot, being the cotyledons removed (Nakagawa, 1999).

Statistical analysis: the study was conducted in a completely randomized design with four replicates per treatment, each replicate being composed of 50 seeds. Initially, the assumptions of the mathematical model were verified by Action ${ }^{\circledR}$ software (Equipe Estatcamp, 2014). In case of non-compliance with the normality of the errors and homogeneity of the variances, the data were transformed by the methodology $\sqrt{\mathrm{x}}$. The percent data were transformed by the equation: $\arcsin \sqrt{\% / 100}$.

Seeds imbibition forms with SA (germination paper and gerbox for 24 hours) and cultivars were analyzed separately. Data were submitted to analysis of variance by the F test $(\mathrm{p}<0.05)$ and regression analysis $(\mathrm{p}<0.05)$ using the Sisvar ${ }^{\circledR}$ software (Ferreira, 2011). 


\section{Results and Discussion}

The physical and physiological characterization of the seeds of the two commercial cultivars is presented in Table 1. It is observed that both have adequate humidity and germination above $80 \%$, however it is noticed a difference in the physiological quality between these materials. The data of the initial characterization were not submitted to statistical analysis, once the objective was only to characterize the cultivars regarding the physiological quality. According to Marcos Filho (2015b), the correct characterization of seed lot quality is extremely important in the use of vigor tests and to understand the results that can be found in the most diverse studies.

Table 1. Thousand seed weight (TSW), moisture (M), first count (FC), germination (G), radicle length (RL), shoot length (SL), radicle dry mass (RDM), shoot dry mass (SDM), electrical conductivity (EC), field emergence (FE) and emergence speed index (ESI) of soybean seeds Tec Irga 6070 RR and NA 5909 RG

\begin{tabular}{|c|c|c|c|c|c|c|c|c|c|c|c|}
\hline Cultivar & TSW & Moisture & $\mathrm{FC}$ & G & $\mathrm{RL}$ & SL & RDM & SDM & EC & $\mathrm{FE}$ & ESI \\
\hline & $\mathrm{g}$ & 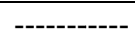 & $-\cdots$ & 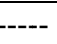 & ---- & m ----- & 1 & g ----- & $\mu \mathrm{S} \mathrm{cm}^{-1} \mathrm{~g}^{-1}$ & $\%$ & \\
\hline Tec Irga 6070 RR & 137 & 12,97 & 83 & 92 & 7,6 & 14,9 & 87 & 198 & 55,8 & 97 & 14,3 \\
\hline NA 5909 RG & 163 & 9,85 & 67 & 93 & 9,0 & 4,4 & 74,5 & 166,2 & 70,9 & 84 & 7,5 \\
\hline
\end{tabular}

The data on vigor and germination for both cultivars and imbibition forms are shown in Figure 1. There was no significant difference in the germination for the cultivar Tec Irga 6070 RR (Figures 1A and 1B). In general, it is noted that the vigor and germination are very similar for the two materials and imbibition method. Thus, at concentrations ranging from 250 and $1000 \mu \mathrm{M}$ occurred the increase of the percentage values, however, from 1000 to $5000 \mu \mathrm{M}$ these values decreased. In comparison with the control, concentrations of 500 and $750 \mu \mathrm{M}$ demonstrated the highest values (Figures 1A-1D). Once there was no type of stress involved, these results were due to the concentrations of SA used.
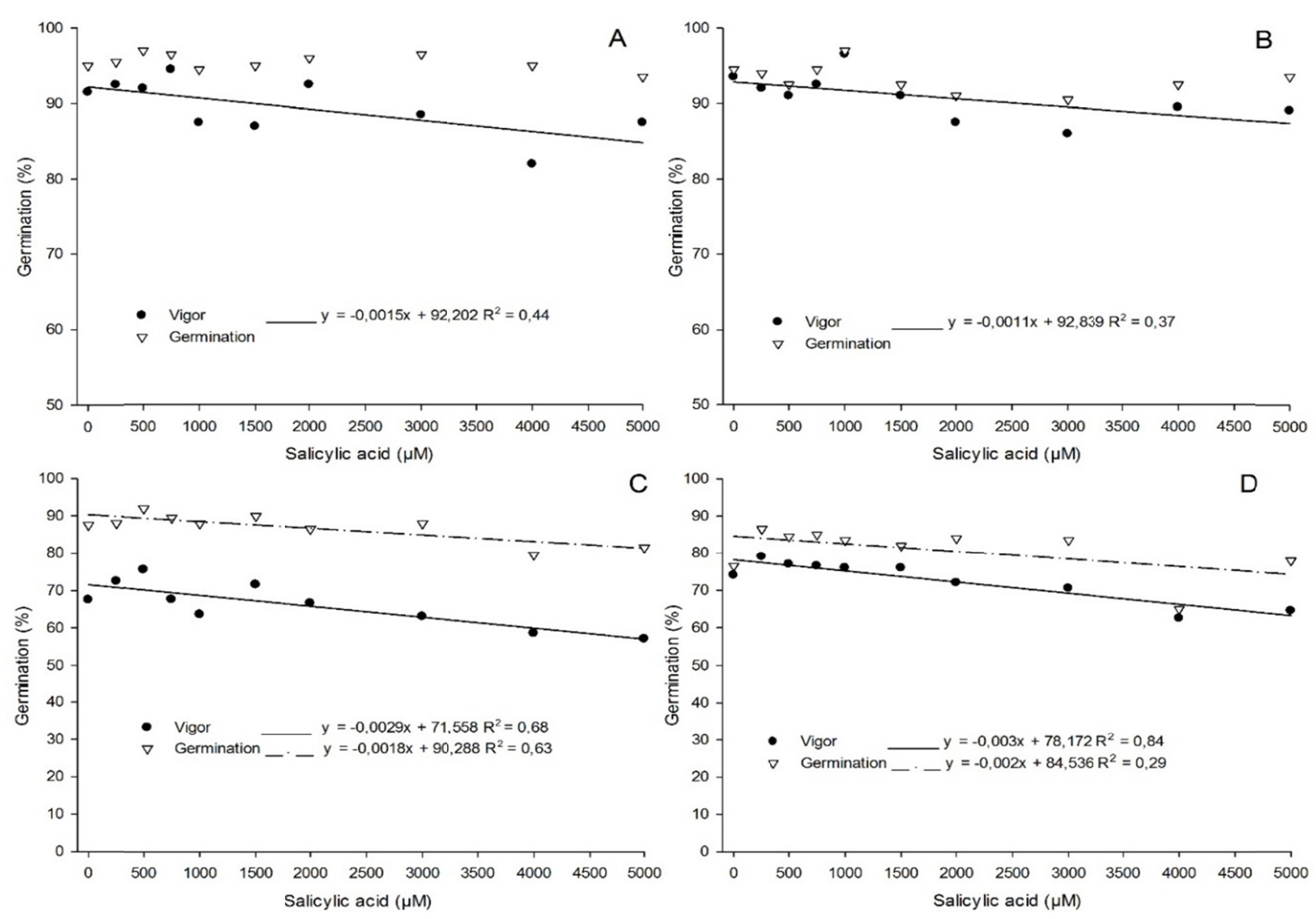

Figure 1. Percentage of vigor and germination for the plants Tec Irga 6070 RR (A) paper, (B) gerbox and NA 5909 RG (C) paper and (D) gerbox 
Most studies report that positive results with SA are usually found in the presence of stress. For example, Al-Hakimi (2006) detected increases in the cell wall metabolism of leaves and roots of soybeans using the concentration of $600 \mu \mathrm{M}$ with the presence of water deficit. In the same context, Lee, Kim, and Park (2010) showed that under normal conditions during the germination process the SA is not essential, only in the stress situation.

Therefore, the significance of high and low concentrations of SA may vary according to species, type of stress evaluated, the period of imbibition or contact of seeds, absorption medium and even the parameters and target of study. Parmoon et al. (2017) evaluated the treatment of seeds of Sylibum marianum with SA, and concluded that concentration of $1000 \mathrm{mg} \mathrm{L}^{-1}$ considerably improved germination and vigor of the aged seeds and seedling growth, in addition to the greater antioxidant activity.

Interestingly, Siddiqui et al. (2018) used $100 \mu \mathrm{M}$ of SA in the treatment of wheat seeds, and there was an increase in germination and plant height due to the increase of proline and total soluble carbohydrates that suppressed the formation of EROs in the roots. It is observed that this concentration is lower than that used in our study, therefore, depending on the species, the sensitivity and response to SA may be completely different.

Figure 2 shows the seedling lengths for each organ and total. Again, the behavior of both materials was similar, but on the germination paper, the values were lower for the three variables studied (Figures $2 \mathrm{~A}$ and $2 \mathrm{C}$ ). In gerbox there was an increase comparing the imbibition methods (Figures 2B and 2D). It is noteworthy that there was a different behavior for Tec Irga $6070 \mathrm{RR}$ in the gerbox, which at the concentration of $5000 \mu \mathrm{M}$ there was an increase in the values, the same did not occur in the paper and for the cultivar NA 5909 RG.
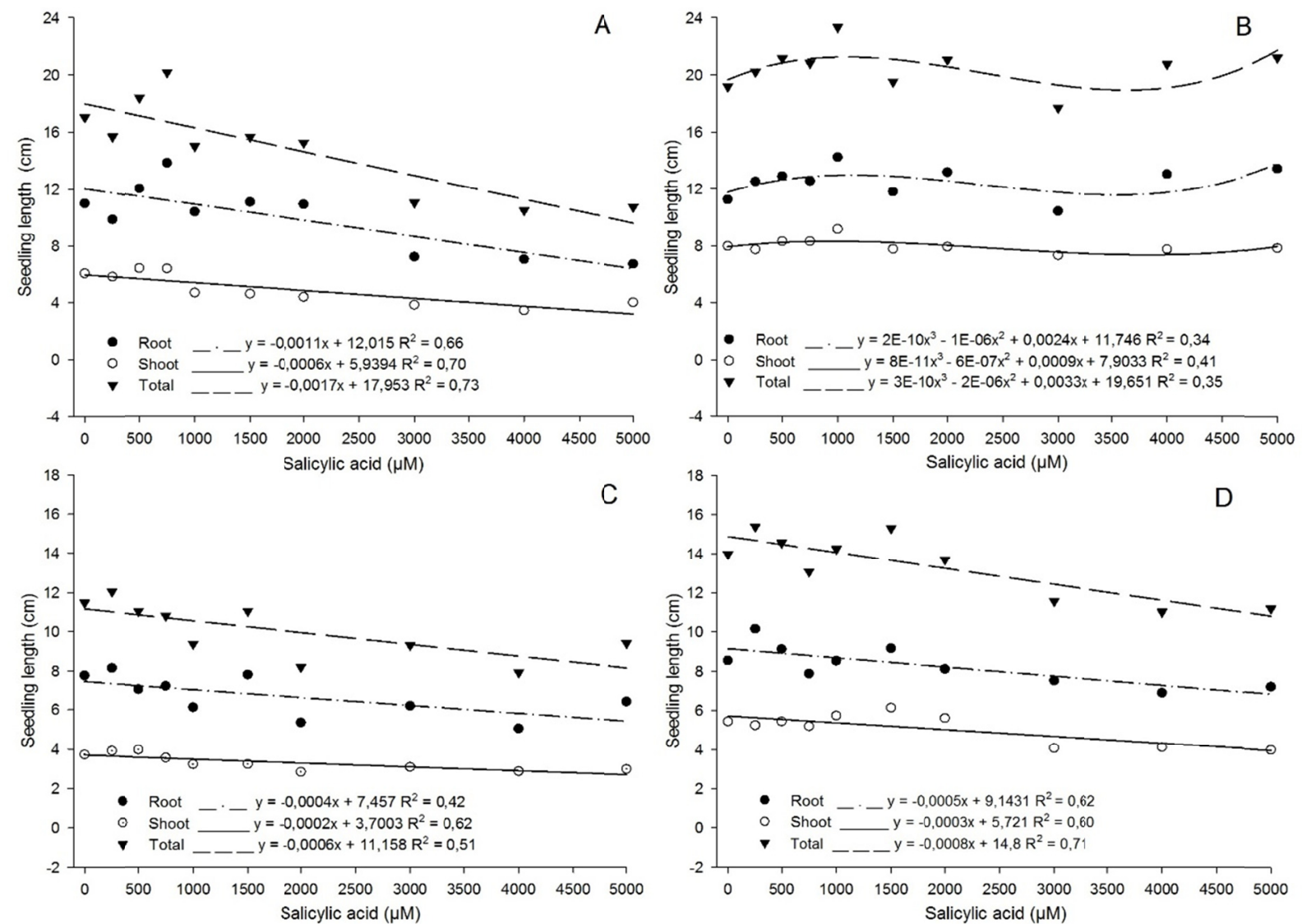

Figure 2. Root, shoot and total length for the cultivars Tec Irga 6070 RR (A) paper, (B) gerbox and NA 5909 RG (C) paper and (D) gerbox

The time of contact of the concentrations with the seeds in each method was different, and this factor may have contributed to the difference in SA absorption. Taking this into account, it is inferred that as a defense practice, at the highest concentrations, such as 4000 and $5000 \mu \mathrm{M}$, the seedling in an attempt to alleviate the possible stress caused, emitted root and shoot to overcome this moment, however, for NA 5909 RG this behavior was different. 
High concentrations of SA lead to oxidative stress and an increase in EROs that impair cellular function at low concentrations, such as $10 \mu \mathrm{M}$ SA, used by Lan et al. (2016) resulted in less accumulation of aluminum in soybean roots and in the activation of antioxidant enzymes, which helps to reduce the stress caused by this element.

The fresh mass values for the two cultivars and imbibition methods are described in Figure 3. Similar to that exposed for the dry mass variable (Figure 2), the fresh mass behavior exhibited a trend of higher weights for the gerbox method and smaller in the paper. In addition, the range of concentrations between 250 and $1000 \mu \mathrm{M}$, but mainly at 500 and $750 \mu \mathrm{M}$, showed the highest fresh root weight, shoot and total weight for both cultivars. Likewise, in the majority of cases, concentrations above $1000 \mu \mathrm{M}$ affected the parameters evaluated (Figure 3).
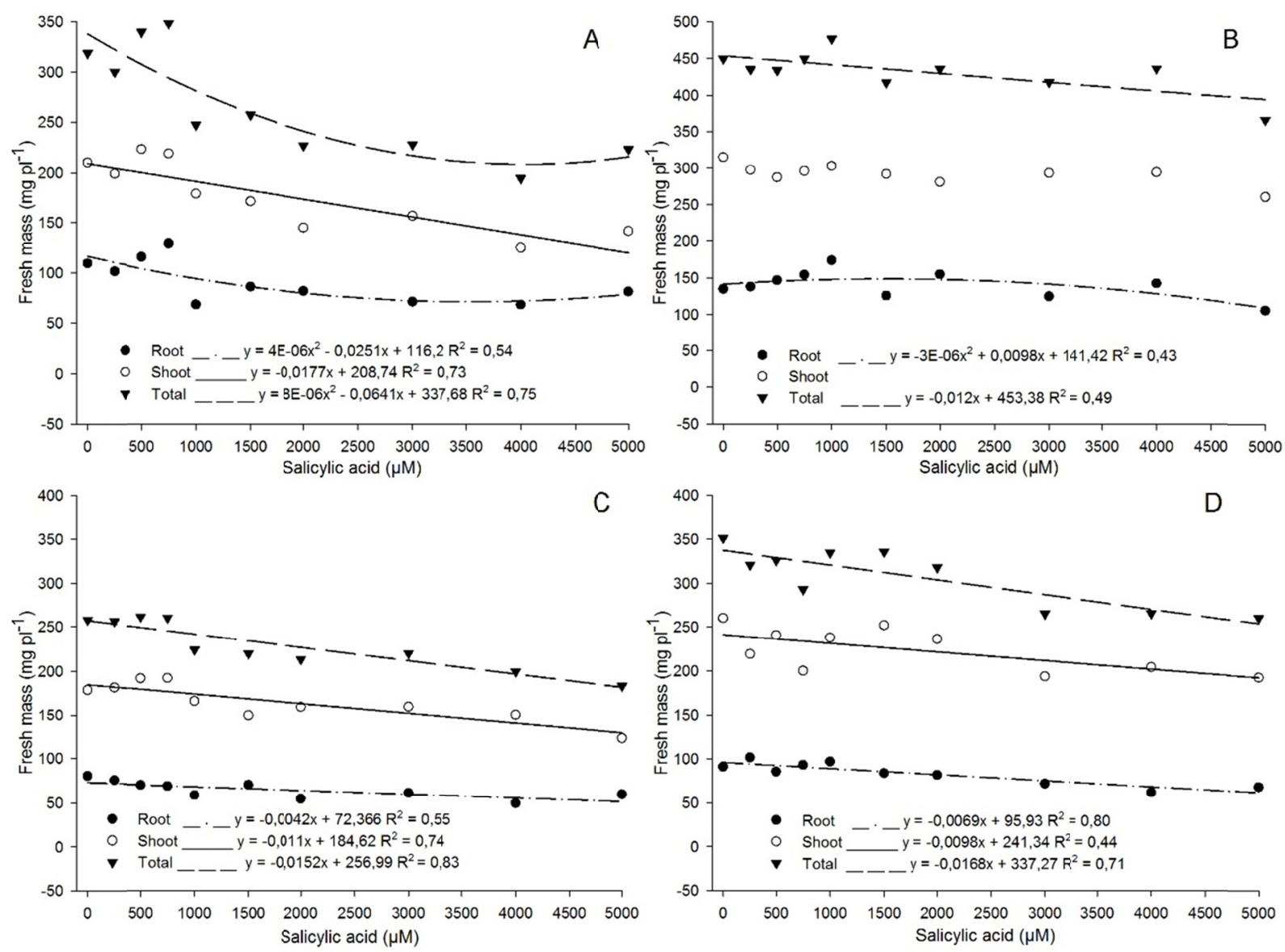

Figure 3. Fresh root, shoot and total mass for the cultivars Tec Irga 6070 RR (A) paper, (B) gerbox, and NA 5909 RG (C) paper and (D) gerbox

These results are similar to those obtained by Coronado, López, and Saavedra (1998), where the foliar application of SA with concentrations higher than $5000 \mu \mathrm{M}$ in soybean yielded increases in leaf length and mainly root values. However, this was a field situation, where higher concentrations of SA may be required. In these situations, root growth may be potentiated after treatment with SA, giving the plant greater ability to absorb water and nutrients during times of water stress (Kadioglu et al., 2011).

Figure 4 shows the dry mass values for the two cultivars and imbibition methods. As expected, again the tendency that occurred in the previous variables was noticed for the dry mass, because there was a decrease in the fresh mass and length in concentrations higher than $1000 \mu \mathrm{M}$ and mainly in $5000 \mu \mathrm{M}$. 

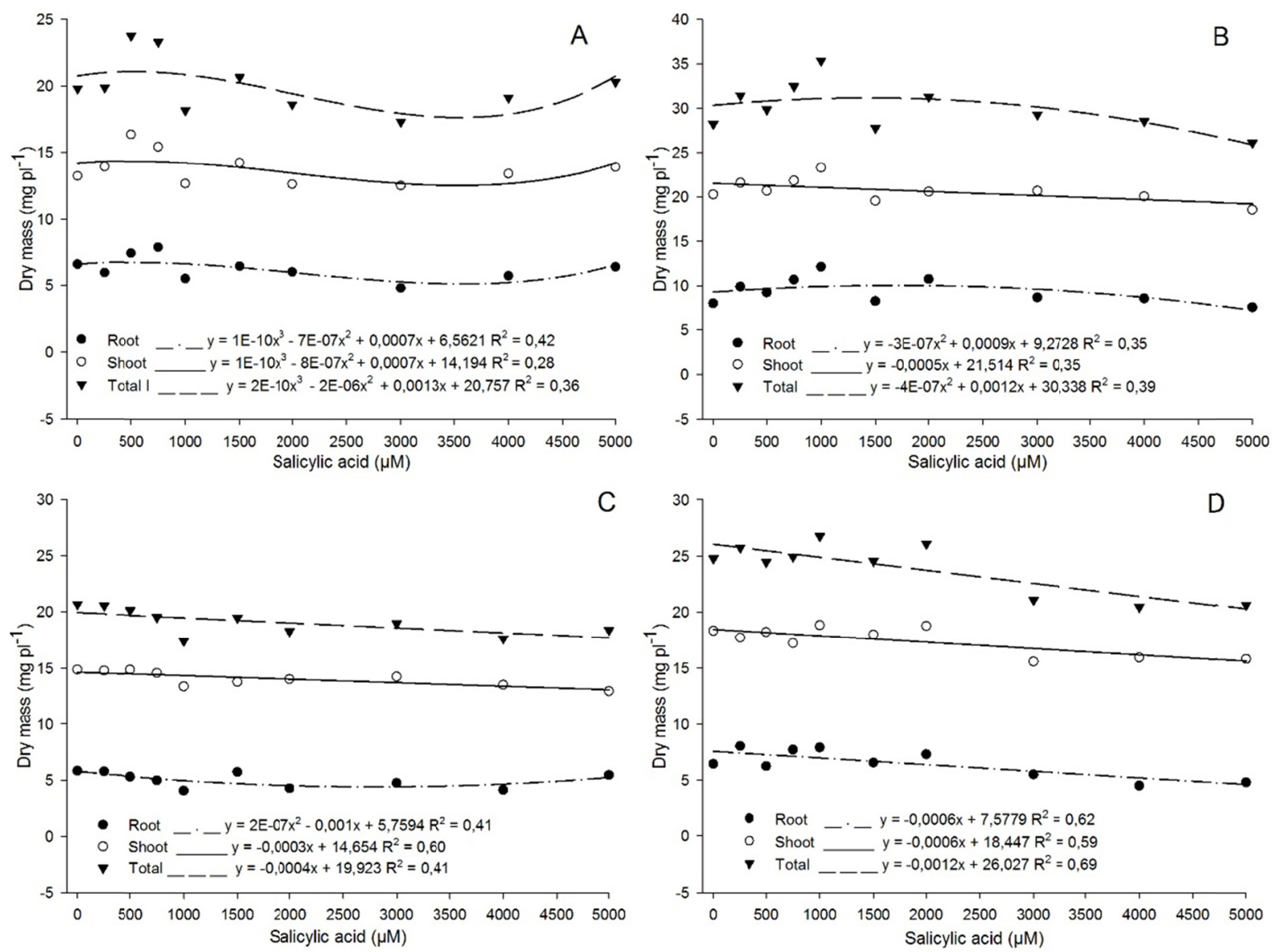

Figure 4. Dry root, shoot and total mass for the cultivars Tec Irga 6070 RR (A) paper, (B) gerbox and NA 5909 $\mathrm{RG}(\mathrm{C})$ paper and (D) gerbox

Therefore, for the dry mass in the two methods in both cultivars the result was similar, and the concentrations between 250 and $7000 \mu \mathrm{M}$ showed the best results, being these values higher than the control group in many cases. Differently, Al Sahil (2016) did not detect a significant increase of fresh, dry mass and seedling length with the use of SA in the concentrations of 0.5 and $1 \mathrm{ppm}$, only in the association with gibberellin for the percentage of germination under saline stress in seeds of cucumber. Similarly, Mazraei1, Ganjalil, and Rad (2016) did not reach significance for the parameters of thousand seed weight and wheat yield using the concentrations 900, 1800 and $2700 \mu \mathrm{M}$.

Lisboa et al. (2017) observed that for different sweet sorghum cultivars, there was drastic reduction of parameters such as germination, germination speed index, number of leaves, length and dry mass of shoot and root in concentrations ranging from 5000 to $20000 \mu \mathrm{M}$. This suggests that it is not necessary to use concentrations above $5000 \mu \mathrm{M}$ and that the use of SA concentrations in the range between 250 and $1000 \mu \mathrm{M}$ can be used in soybean aiming less damage in face of different kind of stresses. In addition, only 24 hours of imbibition in the gerbox method showed an increase in most variables evaluated. For the paper method, there were also variables with increase in values, however, the values are smaller when compared to the time of 24 hours of imbibition of the seeds in gerbox. These results corroborate with Gupta, Meena and Datta, (2017) which used $500 \mu \mathrm{M}$ of SA and observed the increase of germination, root length and aerial part, fresh and dry mass of soybean under heavy metal stress.

The method of application of SA also showed interference. In this context, positive results were found by Kuchlan, Kuchlan, and Husain (2017), where SA foliar application provided higher productivity, sanity, germination, and vigor of soybean seeds during storage. Similarly, the same methods used by Fernandes et al. (2019) in the bean culture showed that 24 hours of imbibition, as opposed to the germination paper, up to 1000 $\mu \mathrm{M}$ provided positive results for germination and other variables analyzed. In fact, this concentration range proved to be the most adequate in the evaluated parameters, serving as the basis for the work and according to 
the literature.

Therefore, future work should be carried out in an attempt to elucidate the parameters of different species, including in the soybean crop. Many of these studies show that there is a concrete effect on the antioxidant activity against biotic and abiotic stresses, and extensive studies are already underway to determine role of this plant hormone by molecular technics (Kang, Li, \& Guo, 2014).

Thus, it is suggested that concentrations above $1000 \mu \mathrm{M}$ impair the evaluated parameters, and the range between 250 and $750 \mu \mathrm{M}$ can be used in future studies with soybean seeds to evaluate the behavior under stress. In addition, the gerbox method for 24 hours provided the best results without drastic decrease of the parameters in lower concentrations of SA.

\section{Conclusions}

Concentrations of SA between 250 and $750 \mu \mathrm{M}$ can be used in soybean seeds, however, above $1000 \mu \mathrm{M}$, the use of this compound may impair physiological quality parameters.

The gerbox method for 24 hours provided the best results without drastic reduction of the parameters in the lowest concentrations of SA.

\section{References}

Alamri, S. A., Siddiqui, M. H., Al-Khaishani, M., \& Ali, H. M. (2018). Response of salicylic acid on seed germination and physio-biochemical changes of wheat under salt stress. Acta Scientific Agriculture, 2(5), 36-42. https://actascientific.com/ASAG/pdf/ASAG-02-0079.pdf

Al-Hakimi, A. M. A. (2006). Counteraction of drought stress on soybean plants by seed soaking in salicylic acid. International Journal of Botany, 2(4), 421-426. https://doi.org/10.3923/ijb.2006.421.426

Al-Sahil, A. A. (2016). Effect of gibberellic and salicylic acids pre-soaking on seed germination attributes of cucumber (Cucumis sativus L.) under induced salt stress. Cercetări Agronomice în Moldova, 49(1), 99-109. https://doi.org/10.1515/cerce-2016-0009

Brasil, Ministério da Agricultura, Pecuária e Abastecimento. (2009). Regras para análise de sementes (p. 395). Secretaria de Defesa Agropecuária. Brasília: MAPA/ACS.

Danquah, A., Zelicourt, A., Colcombet, J., \& Hirt, H. (2014). The role of ABA and MAPK signaling pathways in plant abiotic stress responses. Biotechnology Advances, 32, 40-52. https://doi.org/10.1016/j.biotechadv. 2013.09.006

Equipe Estatcamp. (2014). Software Action. Estatcamp-Consultoria em estatística e qualidade, São Carlos-SP, Brasil. Retrieved from http://www.portalaction.combr

Fernandes, T. S., Nunes, U. R., Roso, R., Ludwig, E. J., Zini, P. B., Menegaes, J. F., ... Santos, C. V. (2019). Physiological quality of common bean seeds subjected to different concentrations of salicylic acid. Journal of Agricultural Science, 11(1), 448-458. https://doi.org/10.5539/jas.v11n1p448

Ferreira, D. F. (2011). Sisvar: A computer statistical analysis system. Ciência e Agrotecnologia, 35(6), 1039-1042. https://doi.org/10.1590/S1413-70542011000600001

Fioreze, S. L., Pivetta, L. G., Fano, A., Machado, F. R, \& Guimarães, V. F. (2011). Comportamento de genótipos de soja submetidos a déficit hídrico intenso em casa de vegetação. Revista Ceres, 58(3), 342-349. https://doi.org/10.1590/S0034-737X2011000300015

Gupta, S., Meena, K. M., \& Datta, S. (2017). The alleviating effect of salicylic acid on early seedling growth of soybean under zinc and lead stress. Bulletin of Environment, Pharmacology and Life Sciences, 6(4), 48-54. Retrieved from http://www.bepls.com/beplsmarch2017/10.pdf

Gutiérrez-Coronado, M. A., Trejo-López, C., \& Larqué-Saavedra, A. (1998). Effect of salicylic acid on the growth of roots and shoots in soybean. Plant Physiology and Biochemistry, 36, 563-565. https://doi.org/ 10.1016/S0981-9428(98)80003-X

Hayat, Q., Hayat, S., Alyemeni, M. N., \& Ahmad, A. (2012). Salicylic acid mediated changes in growth, photosynthesis, nitrogen metabolism and antioxidant defense system in Cicer arietinum L. Plant Soil Environment, 58(9), 417-423. https://doi.org/10.17221/232/2012-PSE

Hayat, Q., Shamsul, H., Mohd, I., \& Aqil, A. (2010). Effect of exogenous salicylic acid under changing environmental: A review. Environmental and Experimental Botany, 68(1), 14-25. https://doi.org/10.1016/ j.envexpbot.2009.08.005 
Jaleel, C. A., Paramasivam, M., Abdul, W., Muhammad, F., Hameed, J. A. J., Ramamurthy, S., \& Rajaram, P. (2009). Drought stress in plants: A review on morphological characteristics and pigments composition. International Journal of Agriculture and Biology, 11(1), 100-105. Retrieved from https://pdfs.semantics cholar.org/fc62/ad94f99b818ee7f9aca6 d879b434b04ba609.pdf

Janda, M., \& Ruelland, E. (2015). Magical mystery tour: Salicylic acid signaling. Environmental and Experimental Botany, 114, 117-128. https://doi.org/10.1016/j.envexpbot.2014.07.003

Janda, T., Gondor, O. K., Szalai, G., \& Pál, M. (2014). Salicylic acid and photosynthesis: signalling and effects. Acta Physiologiae Plantarum, 36(10), 2537-2546. http://doi.org/10.1007/s11738-014-1620-y

Kadioglu, A., Saruhan, N., Saglam, A., Terzi, R., \& Acet, T. (2011). Exogenous salicylic acid alleviates effects of long term drought stress and delays leaf rolling by inducing antioxidant system. Plant Growth Regul, 64, 27-37. https://doi.org/10.1007/s10725-010-9532-3

Kang, G., Li, G., \& Guo, T. (2014). Molecular mechanism of salicylic acid-induced abiotic stress tolerance in righer plants. Acta Physiologiae Plantarum, 36(9), 2287-2297. https://doi.org/10.1007/s11738-014-1603-z

Kang, G., Li, G., Xu, W., Peng, X, Han, Q., \& Guo, T. (2012). Proteomics reveals the effects of salicylic acid on growth and tolerance to subsequent drought stress in wheat. Journal Proteome Research, 11, 6066-6079. https://doi.org/10.1021/pr300728y

Kuchlan, P., Kuchlan, M. K., \& Husain, S. M. (2017). Effect of foliar application of growth activator, promoter and antioxidant on seed quality of soybean. Legume Research, 40(2), 313-318. Retrieved from https://arccjournals.com/uploads/articles/16LR3590.pdf

Lan, T., Jiangfeng, Y., Lingnan, K., Miao, Y., Minghui, L., \& Zhenming, Y. (2016). The interaction of salicylic acid and $\mathrm{Ca}^{2+}$ alleviates aluminum toxicity in soybean (Glycine max L.). Plant Physiology and Biochemistry, 98, 146-154. https://doi.org/10.1016/j.plaphy.2015.11.019

Lee, S., Kim, S. G., \& Park, C. M. (2010). Salicylic acid promotes seed germination under high salinity by modulating antioxidant activity in Arabidopsis. New Phytologist, 188(2), 626-637. https://doi.org/10.1111/ j.1469-8137.2010.03378.x

Lisboa, L., Lapaz, A. M., Viana, R. S., Leonezi, R. S., \& Fgueiredo, P. A. M. (2017). Influência do ácido salicílico no processo germinativo de sementes de cultivares de sorgo sacarino. Acta Iguazu, 6(2), 37-49. Retrieved from http://e-revista.unioeste.br/index.php/actaiguazu/ article/view/17446

Marcos Filho, J. (2015a). Fisiologia de sementes de plantas cultivadas (p. 659). Londrina: ABRATES.

Marcos Filho, J. (2015b). Seed vigor testing: An overview of the past, present and future perspective. Scientia Agrícola, 72(4), 363-374. https://doi.org/10.1590/0103-9016-2015-0007

Mazraei, M., Ganjali, H. R., \& Rad, M. R. N. (2016). The influence of salicylic acid on 1000 grain weight, germination percent and biological yield of wheat in the sistan region. Chemistry Research Journal, 1(4), 157-160. Retrieved from http://chemrj.org/the-influence-of-salicylic-acid-on-1000-grain-weight-germinatio n-percent-and-biological-yield-of-wheat-in-the-sistan-region/

Miura, K., \& Tada, Y. (2014). Regulation of water, salinity, and cold stress responses by salicylic acid. Frontiers Plant Science, 5(4), 1-12.http://doi.org/10.3389/fpls.2014.00004

Morando, R., Silva, A. O., Carvalho, L. C., \& Pinheiro, M. P. M. A. (2014). Déficit hídrico: efeito sobre a cultura da soja. Journal of Agronomic Sciences, 3, 114-129. Retrieved from http://www.dca.uem.br/V3NE/10.pdf

Nakagawa, J. (1999). Testes de vigor baseados no desempenho de plântulas. In F. C. Krzyzanowski, R. D. Vieira, J. B. França Neto (Eds.), Vigor de sementes: Conceitos e testes (p. 218). Londrina: ABRATES.

Parmoon, G., Ebadie, A., Jahanbakhsh, S., \& Mossavi, S. A. (2017). Effect of salicylic acid on antioxidant enzyms of accelerated aging seeds of milk thistle (Silybum marianum). Journal of Plant Process and Function, 6(20), 1-7.

Tang, Y., Sun, X., Wen, T., Liu, M., Yang, M., \& Chen, X. (2017). Implications of terminal oxidase function in regulation of salicylic acid on soybean seedling photosynthetic performance under water stress. Plant Physiology and Biochemistry, 112, 19-28. https://doi.org/10.1016/j.plaphy.2016.11.016

Vazirimehr, M. R., \& Rigi, K. (2014). Effect of salicylic acid in agriculture. International Journal of Plant, Animal and Environmental Sciences, 4(2), 291-296. Retrieved from https:/www.ijpaes.com/admin/php/ uploads/516_pdf.pdf 
Yan, S., \& Dong, X. (2014). Perception of the plant immune signal salicylic acid. Current Opinion in Plant Biology, 20, 64-68. https://doi.org/10.1016/j.pbi.2014.04.006

\section{Copyrights}

Copyright for this article is retained by the author(s), with first publication rights granted to the journal.

This is an open-access article distributed under the terms and conditions of the Creative Commons Attribution license (http://creativecommons.org/licenses/by/4.0/). 